\title{
Surgical treatment of bicuspid aortic valve disease: Knowledge gaps and research perspectives
}

\author{
Alessandro Della Corte, MD, PhD, ${ }^{a}$ Simon C. Body, MBChB, MPH, ${ }^{\mathrm{b}}$ Anna M. Booher, MD, ${ }^{\mathrm{c}}$ \\ Hans-Joachim Schaefers, MD, ${ }^{\mathrm{d}}$ Rita K. Milewski, MD, PhD, ${ }^{\mathrm{e}}$ Hector I. Michelena, MD, \\ Arturo Evangelista, MD, PhD, ${ }^{\mathrm{g}}$ Philippe Pibarot, DVM, PhD, ${ }^{\mathrm{h}}$ Patrick Mathieu, MD, ${ }^{\mathrm{h}}$ \\ Giuseppe Limongelli, MD, PhD, ${ }^{i}$ Prem S. Shekar, MD, ${ }^{j}$ Sary F. Aranki, MD,${ }^{j}$ Andrea Ballotta, MD, ${ }^{k}$ \\ Giuseppe Di Benedetto, MD, ${ }^{1}$ Natzi Sakalihasan, MD, PhD,${ }^{\mathrm{m}}$ Gianantonio Nappi, MD, ${ }^{\mathrm{a}}$ \\ Kim A. Eagle, MD, ${ }^{\mathrm{c}}$ Joseph E. Bavaria, MD, ${ }^{\mathrm{e}}$ Alessandro Frigiola, MD, ${ }^{\mathrm{k}}$ and Thoralf M. Sundt, MD, \\ on behalf of the International Bicuspid Aortic Valve Consortium (BAVCon) Investigators
}

$\mathcal{B}$ Supplemental material is available online.

\section{Sempre la pratica deve essere edificata sopra la bona teorica. [Practice must always be founded on sound theory.]}

—Leonardo Da Vinci (1452-1519; provided the first depiction of a bicuspid aortic valve)

Research on bicuspid aortic valves (BAV) and associated conditions is increasing exponentially. A major part of the current knowledge on BAV is derived from investigations carried out in the clinical setting, especially the surgical setting, as a consequence of the epidemiologic and surgical importance of its valvular and vascular complications. For

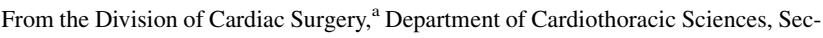
ond University of Naples, Naples, Italy; Department of Anesthesiology, Perioperative and Pain Medicine, ${ }^{\mathrm{b}}$ Brigham and Women's Hospital, Harvard Medical School, Boston, Mass; Division of Cardiology, ${ }^{\mathrm{c}}$ Department of Internal Medicine, University of Michigan Medical Center, Ann Arbor, Mich; Department of Thoracic and Cardiovascular Surgery, ${ }^{\mathrm{d}}$ Saarland University Medical Center, Homburg/Saar, Germany; Department of Cardiovascular Surgery, ${ }^{\mathrm{e}}$ Hospital of the University of Pennsylvania, Philadelphia, Pa; Division of Cardiovascular Diseases, ${ }^{\mathrm{f}}$ Mayo Clinic, Rochester, Minn; Department of Cardiology, ${ }^{\mathrm{g}}$ Hospital Vall d'Hebron, Barcelona, Spain; Laval University, ${ }^{\text {h }}$ Québec, Canada; Cardiology Division, ${ }^{\mathrm{i}}$ Monaldi Hospital, Second University of Naples, Naples, Italy; Division of Cardiac Surgery, ${ }^{\mathrm{j}}$ Brigham and Women's Hospital, Harvard Medical School, Boston, Mass; Department of Cardiac Surgery, ${ }^{\mathrm{k}}$ IRCCS Policlinico San Donato, Milan, Italy; Heart Department, ${ }^{1}$ University Hospital, Salerno, Italy; Cardiovascular Surgery Service, ${ }^{\mathrm{m}}$ University Hospital, Liège, Belgium; Division of Cardiac Surgery, ${ }^{\mathrm{n}}$ Massachusetts General Hospital, Harvard Medical School, Boston, Mass.

Disclosures: Simon C. Body reports consulting fees from AbbVie. Kim A. Eagle reports a research grant from Gore. Thoralf $\mathrm{M}$. Sundt reports consulting fees from Thrasos Therapeutics, Inc. All other authors have nothing to disclose with regard to commercial support.

Received for publication Jan 4, 2014; accepted for publication Jan 17, 2014; available ahead of print Feb 16, 2014

Address for reprints: Alessandro Della Corte, MD, PhD, Department of Cardiothoracic Sciences, Second University of Naples, c/o V. Monaldi Hospital, via L Bianchi 80131, Naples, Italy (E-mail: aledellacorte@libero.it).

J Thorac Cardiovasc Surg 2014;147:1749-57

$0022-5223 / \$ 36.00$

Copyright (c) 2014 by The American Association for Thoracic Surgery

http://dx.doi.org/10.1016/j.jtcvs.2014.01.021
}

example, most of the stenotic valves explanted at the time of aortic valve replacement are congenitally malformed. However, BAV is most frequently a clinically silent condition until those complications occur. Thus, although previous clinical research has contributed to increase the awareness of the problem, it has been most often limited by an inherent referral bias related to clinical and surgical presentation. The current basic knowledge of BAV, particularly its causes, mechanisms, and early interventions, is probably more limited than generally believed. ${ }^{2,3}$

Surgical treatment of the most common complications of congenital BAV is not believed to be a particular challenge today, at least from a merely technical perspective. Replacement of the valve and/or the aorta can be performed with very low early mortality and morbidity, and in the past 20 years, valve repair has become an additional available option for the regurgitant $\mathrm{BAV}{ }^{4}$ However, it is now increasingly recognized that the scientific basis for surgical management criteria is still rudimentary $^{3-6}$ and persistent gaps in knowledge of the genetics, pathophysiology, and clinical history of BAV are responsible for inconsistencies in surgical practice and lack of a rational and patient-tailored approach. ${ }^{6,7}$ A recent survey among cardiac surgeons on BAVassociated aortopathy showed that the timing and technique of surgical treatment is most often dictated by surgeon preference or institutional policy rather than being tailored to the individual patient's features and disease characteristics. ${ }^{7}$ Frequently, the surgeon's decision regarding timing of an intervention is even in disagreement with the current guidelines from professional societies. $^{4-7}$

The International Bicuspid Aortic Valve Consortium (BAVCon) has been created for the purpose of identifying and addressing current knowledge gaps in BAV, taking advantage of different sources of data, expertise, multiple specialties, and available methodologies from different participating institutions (Appendix E1). The present review focuses on the controversial or unexplored aspects of BAV that are relevant to the surgical management and 


\section{Abbreviations and Acronyms}

$$
\begin{aligned}
\text { ACC }= & \text { American College of Cardiology } \\
\text { AVR } & \text { aortic valve replacement } \\
\text { BAV } & \text { bicuspid aortic valve } \\
\text { BAVCon }= & \text { International Bicuspid Aortic Valve } \\
& \text { Consortium } \\
\text { TAV } & \text { tricuspid aortic valve } \\
\text { TAVR }= & \text { transcatheter aortic valve } \\
& \text { replacement }
\end{aligned}
$$

will be among the research objectives of the Consortium in the coming years. Rather than reiterating the state of the art in surgical management of BAV and its sequelae, this review highlights the gray zones within current knowledge and the questions that remain unanswered, and proposes new research avenues for their resolution.

\section{BICUSPID AORTIC VALVULOPATHY}

\section{Two Leaflets Instead of 3: Any Surgical Implications?}

In terms of both postoperative in-hospital/30-day mortality and complications, early outcomes of valve surgery for BAV do not differ from those for tricuspid aortic valve disease. ${ }^{8,9}$ Comparing the 2 largest BAV replacement series, it seems that in-hospital mortality has improved over the decades from an average $2.8 \%(1960-1995)^{10}$ to $1.5 \%$ (19902003). ${ }^{11}$ Long-term outcomes are satisfactory, in part explained by the relatively young age of the patients undergoing surgery for BAV. Reported 15-year survival ranged between $68 \%$ and $78 \%$ after isolated aortic valve replacement (AVR), ${ }^{8,12}$ whereas survival was lower when concomitant coronary artery bypass surgery was needed ${ }^{10,12}$ : these figures are not different from those reported for agematched patients with a tricuspid aortic valve (TAV). ${ }^{8}$

Despite such satisfactory surgical outcomes, the scientific basis on which the current surgical approach to bicuspid aortic valvulopathy is founded remains defective. Because recent surgical and clinical research on the topic of BAV has mostly focused on the associated aortopathy, important gaps in knowledge remain on the genetic basis, causative mechanisms, and clinical history of bicuspid valvulopathy. Although current guidelines for surgical treatment of aortic valve dysfunction are well supported, they do not distinguish between the TAV and BAV, ${ }^{13,14}$ Yet patients with BAV disease are generally younger at the time of surgery: their longer life expectancy compared with patients with TAV disease implies longer exposure to valve-related complications (eg, structural deterioration of tissue prostheses, prosthetic endocarditis, and so forth) and greater concerns about lifestyle (eg, sports, exercise, and so forth), or desire for pregnancy. The situation is further complicated by recent studies suggesting that the functional severity of BAV stenosis, as a consequence of its asymmetric geometry, can be greater than assessed by common imaging methods, and so may be its impact on both ventricular remodeling and flow alterations in the ascending aorta. ${ }^{15-17}$ Even the echocardiographically normally functioning BAV opens asymmetrically thus causing an abnormal postvalvular flow pattern and subclinical stenosis. ${ }^{15,18}$ However, it is not yet known whether these notions should influence the timing of surgery. For example, should a mild stenosis be treated at the time of surgery for ascending dilatation if the valve is bicuspid? If not replaced, how fast will it progress to a severe degree or symptomatic stenosis? Can traditional or newer imaging modalities provide reliable predictors of valve stenosis progression in the BAV population? An echocardiography-based valve degeneration score was proposed that proved predictive of aortic valve surgery in the follow-up ${ }^{19}$ : could computed tomography-based criteria/indexes, with the inherent better definition of calcification patterns, add important information to the current limited capability to predict valvulopathy progression? Will genetic tests help in this prediction of the fate of a borderline valve function (Table 1)?

\section{Are All BAVs Equal?}

A significant source of clinical heterogeneity in BAV disease lies in the variable morphology of the valve, that is, patterns of congenital cusp fusion (also referred to as morphotypes). ${ }^{20}$ Evidence has been presented suggesting that different genetic substrates could underlie the diverse morphotypes. ${ }^{21}$ Arguing against this, however, it has been recently found that the 2 most frequent morphotypes (fusion of right-left coronary leaflets and fusion of right noncoronary leaflets) can be interchangeably inherited in familiar forms of BAV. ${ }^{22}$ Thus, to compellingly determine the clinical and surgical implications of differences in the valvular anatomy, future studies will need to include large numbers of patients for each morphotype. Even within a single morphotype, BAVs can be further distinguished for the degree of leaflet fusion, ${ }^{23}$ the characteristics of the raphe if present, and the respective positions of the 2 true commissures. ${ }^{24}$ All these features can affect valve biomechanics in terms of stress and strain, ${ }^{24}$ that is, stimuli that are known to be able to promote valve calcification through the pathways of bone morphogenetic proteins and transforming growth factor $\beta .^{25}$ Thus, a potentially relevant unknown in BAV surgery is whether gross and subtle anatomic variants have any prognostic significance and should be therefore considered in surgical decision making; for example, whether to spare a normally functioning or mildly dysfunctional BAV at the time of surgery for an aortic aneurysm. To increase knowledge on these aspects, surgical cohorts should be specifically stratified according to the valve morphotype (Table 1), instead of including all variants under the same BAV descriptor. 
TABLE 1. Gaps in knowledge and research perspectives in surgery for BAV: key points

\begin{tabular}{|c|c|c|}
\hline Current knowledge & Knowledge gaps & Proposed strategies to improve knowledge \\
\hline \multicolumn{3}{|l|}{ Bicuspid valvulopathy } \\
\hline $\begin{array}{l}\text { Greater flow derangement with BAV stenosis } \\
\text { than with TAV stenosis, for each given } \\
\text { orifice area }\end{array}$ & $\begin{array}{l}\text { Different criteria for indication to AVR according } \\
\text { to valve type (BAV/TAV)? }\end{array}$ & $\begin{array}{l}\text { Comparing the natural history of BAV versus } \\
\text { TAV stenosis. Searching for the predictors of } \\
\text { faster stenosis progression in patients with } \\
\text { BAV }\end{array}$ \\
\hline $\begin{array}{l}\text { The goal of BAV repair surgery: restoring a } \\
\text { coapting and less stressed valve }\end{array}$ & $\begin{array}{l}\text { Which BAV features affect leaflet stress? Which } \\
\text { technique for annular reduction? }\end{array}$ & $\begin{array}{l}\text { Identifying (bioengineering studies, clinical } \\
\text { series) factors affecting long-term durability of } \\
\text { BAV repair }\end{array}$ \\
\hline $\begin{array}{l}\text { TAVR in BAV: concerns of noncircular } \\
\text { deployment (risk of perivalvular leak) }\end{array}$ & $\begin{array}{l}\text { Are BAV calcifications always asymmetric and } \\
\text { the orifice always eccentric? }\end{array}$ & $\begin{array}{l}\text { Identifying imaging criteria for definition of a } \\
\text { subset of patients with BAV for whom TAVR is } \\
\text { feasible }\end{array}$ \\
\hline $\begin{array}{l}\text { Different BAV morphotypes, associated with } \\
\text { unique clinical features and different valve } \\
\text { dysfunction risks }\end{array}$ & $\begin{array}{l}\text { Differential valve surgery approach according to } \\
\text { the morphotype }(\mathrm{RL}, \mathrm{RN}, \mathrm{LN}) \text { ? }\end{array}$ & $\begin{array}{l}\text { Natural history studies on large populations of } \\
\text { patients with BAV, stratifying according to the } \\
\text { valve morphotype }\end{array}$ \\
\hline \multicolumn{3}{|l|}{ Bicuspid aortopathy } \\
\hline $\begin{array}{l}\text { Diverse BAV morphotypes are associated with } \\
\text { different patterns of aortic dilatation }\end{array}$ & $\begin{array}{l}\text { Different surgical approach to the aorta for } \\
\text { different BAV morphotypes (RL, RN, LN)? }\end{array}$ & $\begin{array}{l}\text { Investigating the correlation between valve type } \\
\text { and aortopathy risk and features }\end{array}$ \\
\hline $\begin{array}{l}\text { A proportion of patients with BAV experience } \\
\text { acute aortic dissection at small diameters }\end{array}$ & $\begin{array}{l}\text { Any other nondimensional determinant of the } \\
\text { risk of dissection? }\end{array}$ & $\begin{array}{l}\text { Identifying aortic risk markers (other than } \\
\text { diameter): circulating biomarkers, aortic flow } \\
\text { patterns, wall load-bearing properties, genetic } \\
\text { markers, phenotypic markers }\end{array}$ \\
\hline $\begin{array}{l}\text { Various proposed classification schemes for } \\
\text { the aortic phenotype }\end{array}$ & $\begin{array}{l}\text { Any prognostic significance of the aortic } \\
\text { phenotype; any relevance to surgical timing? } \\
\text { Which classification? }\end{array}$ & $\begin{array}{l}\text { Stratifying longitudinal studies according to the } \\
\text { aortic phenotype. Assessing the prognostic } \\
\text { value of the different classifications in } \\
\text { prospective studies }\end{array}$ \\
\hline $\begin{array}{l}\text { Different phenotypes of aortic dilatation. } \\
\text { Choice of the procedure often left to the } \\
\text { individual surgeon's discretion }\end{array}$ & $\begin{array}{l}\text { Surgical technique tailored to the aortic } \\
\text { phenotype? }\end{array}$ & $\begin{array}{l}\text { Exploring the risk/benefit of tailoring the } \\
\text { procedure to the aortic phenotype }\end{array}$ \\
\hline
\end{tabular}

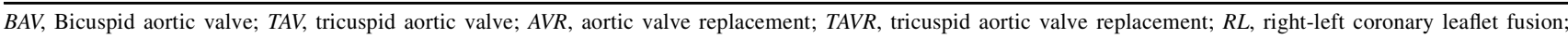
$R N$,right-noncoronary leaflet fusion; $L N$, left-noncoronary leaflet fusion.

Improved understanding of BAV morphologic diversity is advocated also in the setting of transcatheter aortic valve replacement $(\mathrm{TAVR})^{26}$ : although $\mathrm{BAV}$ was initially excluded from the indications to TAVR in the PARTNER trial $^{27}$ because of concerns about the risk of noncircular deployment of the prosthesis as a result of eccentricity of the orifice and asymmetry of calcifications, more recent studies have shown that TAVR can be performed in selected subsets of patients with BAV at high surgical risk with similar success as in patients with $\mathrm{TAV}^{26,28}$ Imaging methods are available today for detailed morphologic phenotyping of $\mathrm{BAV}$, and transcatheter prosthesis design is evolving, therefore the application of TAVR in inoperable patients with BAV is fertile research ground.

\section{The Purely Regurgitant BAV: Replace or Repair?}

Although aortic stenosis in the adult is only treatable by prosthetic valve replacement, aortic regurgitation can be repaired, avoiding anticoagulation-related risks. ${ }^{29}$ Several techniques have been proposed, including plication of redundant leaflet tissue, raphe resection and conjoint cusp reconstruction, pericardial patch augmentation, free-margin reinforcement or resuspension, subcommissural stitching, and suture or ring annuloplasty. Several studies have shown the feasibility of BAV repair, however midterm durability has been inconsistent. ${ }^{30,31}$ It seems logical that the stability of the repair depends on leaflet tissue quality including the degree of fibrosis and calcification. ${ }^{29}$ However, no study has yet tested the risk/benefit of earlier treatment, aimed at performing surgery on a better-preserved cusp structure. Recent evidence indicates that the anatomic features of the BAV may have a strong prognostic impact on the durability of repair. ${ }^{32,33}$ Advancements in our understanding of BAV geometry and kinematics has led to the notion that late BAV repair failures might be incited by abnormal leaflet stresses, inherent to the morphology of the repaired valve. ${ }^{15,24}$ In particular, $40 \%$ lower rates of 10 -year freedom from valve reoperation have been observed in patients with an aorto-ventricular junction diameter exceeding 28 to 30 $\mathrm{mm}$ compared with patients with a smaller diameter, ${ }^{30,32}$ leading to the recent development of different strategies for annular reduction and support. ${ }^{34,35}$ However, the ideal correction of annular dilatation still has to be determined (Table 1). 


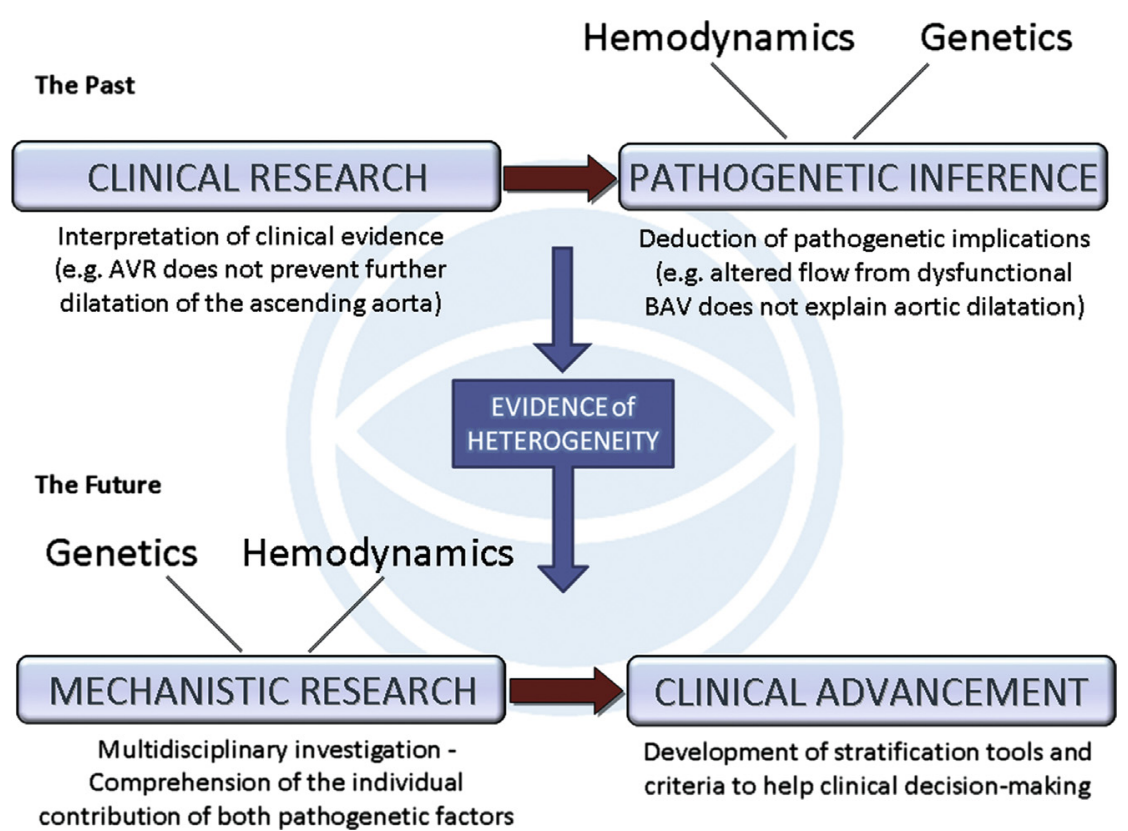

FIGURE 1. The research approach to BAV aortopathy: past and future. Up to a few years ago, research on BAV aortopathy interpreted clinical aspects (eg, rate of progression, relation with severity of valve dysfunction, risk of dissection) with the aim of drawing inferences on the pathogenesis, that is, alternatively supporting the hemodynamic or the genetic theory. Inconclusive results and increasing awareness of the phenotypic heterogeneity have led to an inversely oriented approach: the contribution of either pathogenetic factor is investigated to identify the respective potential prognostic value in the clinical setting. ${ }^{6} A V R$, Aortic valve replacement; $B A V$, bicuspid aortic valve.

The orientation of the 2 true commissures also affects postrepair outcomes; when the commissures are located $160^{\circ}$ to $180^{\circ}$ apart, leaflet stresses are lower ${ }^{24}$ and 10 -year freedom from reoperation rates can be more than $40 \%$ higher than in patients with less than $160^{\circ}$ commissural orientation. ${ }^{32,33}$ It has been pointed out ${ }^{36}$ that although repairing a TAV fundamentally means restoring normal native anatomy, BAV repair requires complete rearrangement of valve orifice geometry, aiming at producing a new, more physiologic flow architecture, with consequent lower leaflet stresses. ${ }^{15,24}$ No definitive evidence has been provided so far in favor or against a systematic or selective surgical reconfiguration of commissural orientation. Also the impact of other BAV morphofunctional details and respective corrective maneuvers on surgical outcomes (ie, recurrence of regurgitation) should be the subject of future studies (Table 1). For this purpose, a combination of best-practice imaging methods and well-codified surgical approaches will be critical.

\section{BAV-ASSOCIATED AORTOPATHY From Practice to Pathogenesis or From Pathogenesis to Practice?}

The general research approach to BAV aortopathy has been inductive in the past, drawing inferences on its pathogenesis from the observation of clinical presentations and outcomes, often in the setting of surgical series. However, a tendency to simplify our view of the problem when translating it into principles of clinical practice has caused an exacerbation of the dichotomy between genetic and hemodynamic theories of aortopathy: proponents of the former endorse greater surgical aggressiveness, those supporting the latter suggest a more conservative posture. ${ }^{37,38}$ This simplistic view has prevented researchers from focusing on the evidence of phenotypic heterogeneity of BAV aortic disease. As a result, both research advances and management innovation have been hampered. Phenotypic heterogeneity suggests that both genetic and hemodynamic processes can coexist, each with variable expression from patient to patient. ${ }^{6}$ In the light of this evidence, an inversion of the inductive process is probably required (Figure 1). The putative mechanisms of causation, that is, both genetics and biomechanics, should be thoroughly addressed with the aim of translating the resulting knowledge into diagnostic/prognostic tools and criteria. In particular, new metrics should be developed for the quantification of the respective contribution of either pathogenetic factor in the individual patient or patient subgroup. With this new research mind set, and the consequent improved ability to stratify patients with BAV according to their aortic risk, important surgical goals may be achieved, including patient-tailored indications and techniques as well as rationalization of choices. ${ }^{2,6}$

\section{When to Operate on the Aorta: Only a Matter of Size?}

The 2010 American Heart Association (AHA)/American College of Cardiology (ACC) guidelines for surgical treatment of aortic diseases did not suggest a unique cut-off 
diameter indicating intervention for BAV aortopathy, but included BAV among systemic connective tissue abnormalities (Marfan, Elher-Danlos, Loeys-Dietz, and so forth) with the same recommendations of "between 40 and $50 \mathrm{~mm}$ " or growth rate exceeding $5 \mathrm{~mm} / \mathrm{y}{ }^{39}$ The evidence supporting those guidelines and the inclusion of BAV among systemic syndromes have been the subject of criticism. ${ }^{5,40,41}$ More specific criteria were included in the 2012 European Society of Cardiology/European Association for CardioThoracic Surgery guidelines for valve diseases, whereby the cut-off is set at $55 \mathrm{~mm}$, or $50 \mathrm{~mm}$ in the case of associated coarctation, family history of dissection, hypertension or growth rate greater than $2 \mathrm{~mm} / \mathrm{y}$, or $45 \mathrm{~mm}$ in the case of valve surgery. ${ }^{14}$ However, the level of evidence supporting current recommendations is still inadequate and guidelines are mostly derived from expert consensus. ${ }^{6,42}$

The lack of knowledge and the absence of consistency between American and European guidelines is echoed by important divergences in practice. Some investigators ${ }^{11,43}$ have used a cut-off of 40 to $45 \mathrm{~mm}$ for surgical aortic resection, others a diameter exceeding $40 \mathrm{~mm}$ in younger patients ${ }^{44}$; others have even reported that in $20 \%$ of their experience, an off-label indication for a diameter of 40 $\mathrm{mm}$ or less was used. ${ }^{45}$ On the other hand, in few European contemporary series of ascending aorta replacement, a conservative criterion of more than $50 \mathrm{~mm}$ was followed, even in the presence of significant valve dysfunction. ${ }^{8,46}$ Among 100 recently interviewed Canadian cardiac surgeons, only $55 \%$ reported replacing the ascending aorta when it exceeds $50 \mathrm{~mm}$ in 50 -year-old patients with BAV without valve dysfunction, whereas $29 \%$ were more aggressive and $16 \%$ were more conservative. ${ }^{7}$

As the anatomic and clinical heterogeneity of BAV disease is increasingly recognized, it becomes evident that the debate on surgical indications is a direct consequence of the lack of data on the prognostic significance of phenotypic differences. For example, although right noncoronary cusp fusion predisposes to earlier development of valve dysfunction in children, it is still unknown whether the individual valvular morphotypes imply a different risk of aortic events (Table 1). Another source of heterogeneity is the pattern of aortic dimensions, namely the aortic phenotypes. ${ }^{47-50}$ Few and small observational studies have examined the clinical importance of the distinct BAV aortic phenotypes. Although the most frequently dilated segment is the tubular supracoronary tract, predominant involvement of the aortic root and sinuses has been associated with faster growth of the aorta and higher rates of aortic events. ${ }^{51-53}$ Larger prospective registries could define whether different dimensional cut-offs for surgery should be used for the 2 aortic tracts (sinus vs tubular) in future recommendations (Table 1). In addition, a lack of uniform methods and definitions of the aortic phenotypes hinders research efforts; for example, should the definition be based on the aortic shape (relation between dimensions at different segments) or should it take the absolute dimen-

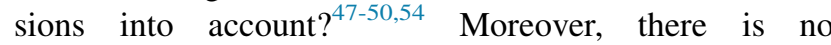
homogeneity in the methods used for indexing the aortic dimensions to the patient's body size. These include the aortic size index (diameter divided by body surface area), ${ }^{7,55}$ the aortic ratio ${ }^{56}$ (observed diameter divided by expected diameter, based on the Roman formulas ${ }^{57}$ ), and the cross-sectional area to height ratio. ${ }^{58}$ The respective suggested cut-offs for surgical indication ${ }^{36,56,58}$ may correspond to different absolute diameters in the same patient: which index has the best sensitivity and specificity as a predictor of aortic events? When should an indexing method be used rather than the absolute dimension (eg, in patients with low stature, female sex, or obesity)?

The International Registry of Acute Aortic Dissections, which included $3 \%$ of patients with $\mathrm{BAV}$, demonstrated that aortic diameter is a poor predictor of acute aortic dissection, as this dreaded complication occurred at diameters less than $50 \mathrm{~mm}$ in about $40 \%$ of patients. ${ }^{59}$ However, a small study reported only $12 \%$ of dissections less than 50 $\mathrm{mm}$ in patients with $\mathrm{BAV},{ }^{58}$ and in a more recent investigation, ${ }^{60}$ the mean diameter at dissection in patients with BAV was $10 \mathrm{~mm}$ greater than in patients with TAV. Therefore, the role of aortic diameter in aortic dissection may be different for BAV and TAV. Nonetheless, these data were derived from retrospective analyses ${ }^{58-60}$ where aortic diameter was assessed after dissection had already occurred. Prospective studies will provide important new insights by determining the rate of aortic dilation and the predissection diameter; given the relatively low incidence of dissection in the BAV population, ${ }^{61}$ a very large study cohort is needed for this purpose. In addition, other studies have demonstrated the lack of correlations between aortic diameter and degree of medial degeneration in the aortic wall of patients with $\mathrm{BAV}^{62}$ as well as between the degree of elastic fiber fragmentation and the occurrence of acute dissection. ${ }^{63}$ Hence, other important unanswered questions emerge: does the aortic diameter need to be integrated into a more complex system of stratification including other risk markers, so that its relative weight in the decision-making process can vary case by case according to other prognostic factors? And what should those other risk markers be (Table 1)?

The answer may be found by reappraising the pathogenesis of aortic dissection as it is currently known. Cornerstone studies, not stratified for valve type (BAV/TAV), established that, on average, $6 \mathrm{~cm}$ is the critical diameter at which a steep increase in the risk of rupture or dissection is observed (of note, no separate analysis was performed for rupture and dissection). ${ }^{64}$ This occurs because, in the average aorta, a $6-\mathrm{cm}$ diameter marks the time point in the natural history of the aortopathy when tissue remodeling 

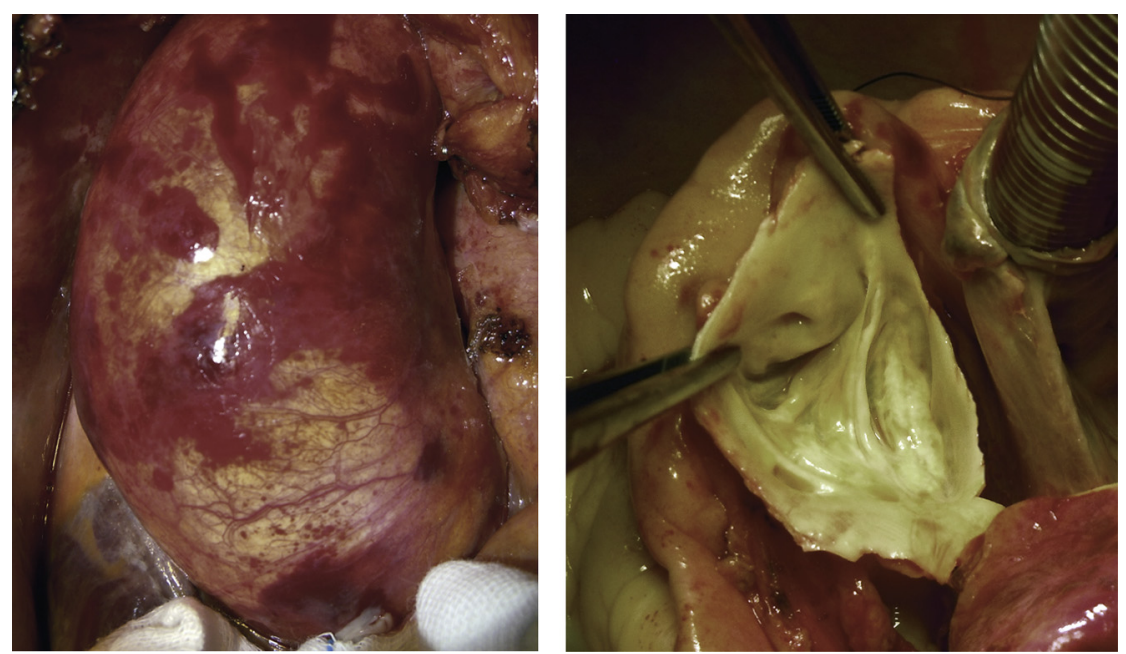

FIGURE 2. Borderline conditions. Intraoperative photographs from a patient with dilated ascending aorta (left: $50 \mathrm{~mm}$ at the midascending tract bulging toward the right and anteriorly, $35 \mathrm{~mm}$ at the sinotubular junction, $38 \mathrm{~mm}$ at sinuses, and normal distal ascending and arch diameters) and BAV (right: fusion of the right and left coronary leaflets, partial fibrous noncalcific raphe, a nearly $180^{\circ}$ position of the commissures, no stenosis, and trivial regurgitation at echocardiography). According to published series, different investigators would treat this unique condition by a variety of techniques, including simple ascending replacement, ascending reduction aortoplasty, ascending and root replacement with valve sparing, Wheat operation, Bentall operation, and so forth. ${ }^{7}$

phenomena have presumably altered the mechanical properties of the wall to the extent that its strength is easily overcome by wall stress. Ideally, to reach individualization of surgical indications, in a way to reduce the incidence of type A dissection as much as possible, we should aim to measure the key players of the process in a patientspecific fashion. This might include quantification of wall remodeling phenomena by assessment of circulating biomarkers ${ }^{65}$ or molecular imaging, estimation of wall properties (thickness, elasticity, stiffness, and distensibility) by methods of functional imaging, ${ }^{66}$ measurement or computation of wall stresses by patient-specific biomechanical simulations, ${ }^{15,67}$ and magnetic resonance imaging of flow patterns. ${ }^{18}$ When the genetics underlying the risk of dissection in patients with BAV aortopathy are elucidated, genetic tests will add dramatically to risk-stratification systems. This will be one of the main efforts of the BAVCon project.

\section{The Extent of Surgical Aortic Resection}

The basic primum non nocere warning for medical practice is often quoted about surgery for BAV aortopathy: indeed, an imprudent conservative approach in a patient at increased risk for dissection but also an excessive extent of resection in a patient with lower risk can be harmful or at least unsafe decisions.

Akin to the indications for aortic surgery, the criteria for the extent of resection are also currently subject to wide variations according to the individual surgeon or center's policies $^{7}$ (Figure 2). In pursuit of a less aggressive approach, reduction aortoplasty, usually of the midascending aorta, has been performed by some investigators. ${ }^{68}$ In selected cases, when a shorter operative time is significantly advantageous, ${ }^{4}$ the success of such an approach may rely on the localized degeneration of the aortic wall at the greater curvature, which is typically associated with BAV stenosis. ${ }^{69}$ However, wider application of this procedure, especially in younger patients with regurgitant $\mathrm{BAV}$, has led to poor long-term results in terms of dilatation recurrence. ${ }^{48,69}$

Although guidelines do not endorse proactive resection of nondilated aortic segments, the general more aggressive surgical posture toward BAV aortopathy ${ }^{70}$ has resulted in more frequent resection of adjacent nondilated segments in patients with BAV with an isolated aneurysm of the tubular ascending aorta. $^{44,71}$ However, both root replacement and arch procedures add incremental risk to midascending tract replacement alone, related to coronary ostia reimplantation and to circulatory arrest, respectively, ${ }^{5,41}$ with increased early postoperative mortality (eg, from $3 \%$ to $9 \%$ if arch replacement is added). ${ }^{72}$

Recent large retrospective studies have demonstrated that sparing an unaffected $\operatorname{root}^{48}$ or $\operatorname{arch}^{73}$ at the time of ascending replacement does not expose the patient to a significant risk of reoperation in the long term. After resection of the ascending aorta, the aortic arch in patients with BAV showed a median growth of $0 \mathrm{~mm} / \mathrm{y} .{ }^{43}$ These observations are consistent with the midascending dilatation being the most frequently observed phenotype of BAV aortopathy. ${ }^{47,52}$ However, considering the high prevalence of BAV in the general population $(0.5 \%-2 \%$ of all live births), and the significant proportion of patients with BAV developing aortic dilatation $(30 \%$ to $>70 \%),{ }^{1-4}$ even 
a low percentage of reoperations on the residual aorta (about $1 \%$ in the Mayo series over a median 3-year follow-up ${ }^{48}$ ) may represent a large health care burden. We advocate that future surgical studies explore the efficacy of a management strategy based on tailoring the resection extent to the individual aortic phenotype and consider other risk-stratifying phenotypic factors as they become available. This will require comparative studies of the very long-term follow-up of different subsets of patients with BAV (Table 1). Besides the different forms of aortic dilatation (ascending phenotype vs root phenotype), other anatomic, genetic, and biochemical features could prove of prognostic significance, thus becoming relevant to the surgical decision. Potential risk-stratifying features may include effacement of the sinotubular junction, ${ }^{4,48}$ unicuspid aortic valve, ${ }^{36}$ associated mitral valve prolapse, ${ }^{51,74}$ or bovine arch. ${ }^{75}$

\section{CONCLUSIONS}

Given its epidemiology and the clinical relevance of related questions and unknowns, BAV will likely continue to represent a priority in cardiovascular research. Besides addressing the strategies and outcomes of surgical treatments for BAV complications, surgeons will have to collaborate with imaging experts and basic researchers to elucidate the mechanisms of development and progression of those complications. BAVCon features a Biobank/Surgery Core whose members will both lead the surgical research on BAV and provide blood and tissue samples for basic research analyses as well as clinical data for refined phenotyping.

Future research on BAV will be of multidisciplinary and translational nature, research objectives will be pursued taking into adequate consideration the heterogeneity and complexity of the disease and within a multispecialty, multicenter registry, so that, ultimately, a clinical approach to BAV will be based on the concepts of phenotypic and genotypic stratification and treatment individualization.

\section{References}

1. Roberts WC, Ko JM. Frequency by decades of unicuspid, bicuspid, and tricuspid aortic valves in adults having isolated aortic valve replacement for aortic stenosis, with or without associated aortic regurgitation. Circulation. 2005;111:920-5.

2. Fedak PW, Verma S. The molecular fingerprint of bicuspid aortopathy. J Thorac Cardiovasc Surg. 2013;145:1334.

3. Losenno KL, Goodman RL, Chu MW. Bicuspid aortic valve disease and ascending aortic aneurysms: gaps in knowledge. Cardiol Res Pract. 2012; 2012:145202.

4. El-Hamamsy I, Yacoub MH. A measured approach to managing the aortic root in patients with bicuspid aortic valve disease. Curr Cardiol Rep. 2009;11:94-100.

5. Sundt TM III. Replacement of the ascending aorta in bicuspid aortic valve disease: where do we draw the line? J Thorac Cardiovasc Surg. 2010;140:S41-4.

6. Della Corte A. Phenotypic heterogeneity of bicuspid aortopathy: a potential key to decode the prognosis? Heart. 2014;100:96-7.

7. Verma S, Yanagawa B, Kalra S, Ruel M, Peterson MD, Yamashita MH, et al. Knowledge, attitudes, and practice patterns in surgical management of bicuspid aortopathy: a survey of 100 cardiac surgeons. J Thorac Cardiovasc Surg. 2013; 146:1033-40.
8. Girdauskas E, Disha K, Borger MA, Kuntze T. Long-term prognosis of ascending aortic aneurysm after aortic valve replacement for bicuspid versus tricuspid aortic valve stenosis. J Thorac Cardiovasc Surg. 2014; 147:276-82.

9. Aicher D, Fries R, Rodionycheva S, Schmidt K, Langer F, Schäfers HJ. Aortic valve repair leads to a low incidence of valve-related complications. Eur J Cardiothorac Surg. 2010;37:127-32.

10. McKellar SH, Michelena HI, Li Z, Schaff HV, Sundt TM III. Long-term risk of aortic events following aortic valve replacement in patients with bicuspid aortic valves. Am J Cardiol. 2010;106:1626-33.

11. Borger MA, David TE. Management of the valve and ascending aorta in adults with bicuspid aortic valve disease. Semin Thorac Cardiovasc Surg. 2005;17: $143-7$.

12. Goland S, Czer LS, De Robertis MA, Mirocha J, Kass RM, Fontana GP, et al Risk factors associated with reoperation and mortality in 252 patients after aortic valve replacement for congenitally bicuspid aortic valve disease. Ann Thorac Surg. 2007;83:931-7.

13. Bonow RO, Carabello BA, Chatterjee K, de Leon AC Jr, Faxon DP, Freed MD, et al. 2008 Focused update incorporated into the ACC/AHA 2006 guidelines for the management of patients with valvular heart disease: a report of the American College of Cardiology/American Heart Association Task Force on Practice Guidelines (Writing Committee to Revise the 1998 Guidelines for the Management of Patients With Valvular Heart Disease): endorsed by the Society of Cardiovascular Anesthesiologists, Society for Cardiovascular Angiography and Interventions, and Society of Thoracic Surgeons. Circulation. 2008;118: e523-661.

14. Vahanian A, Alfieri O, Andreotti F, Antunes MJ, Barón-Esquivias G, Baumgartner $\mathrm{H}$, et al. Guidelines on the management of valvular heart disease (version 2012): the Joint Task Force on the Management of Valvular Heart Disease of the European Society of Cardiology (ESC) and the European Association for Cardio-Thoracic Surgery (EACTS). Eur Heart J. 2012;33:2451-96.

15. Conti CA, Della Corte A, Votta E, Del Viscovo L, Bancone C, De Santo LS, et al. Biomechanical implications of the congenital bicuspid aortic valve: a finite element study of aortic root function from in vivo data. J Thorac Cardiovasc Surg. 2010;140:890-6.

16. Richards KE, Deserranno D, Donal E, Greenberg NL, Thomas JD, Garcia MJ. Influence of structural geometry on the severity of bicuspid aortic stenosis. Am J Physiol Heart Circ Physiol. 2004;287:H1410-6.

17. Santarpia G, Scognamiglio G, Di Salvo G, D'Alto M, Sarubbi B, Romeo E, et al Aortic and left ventricular remodeling in patients with bicuspid aortic valve without significant valvular dysfunction: a prospective study. Int J Cardiol. 2012;158:347-52.

18. Bissell MM, Hess AT, Biasiolli L, Glaze SJ, Loudon M, Pitcher A, et al. Aortic dilation in bicuspid aortic valve disease: flow pattern is a major contributor and differs with valve fusion type. Circ Cardiovasc Imaging. 2013;6:499-507.

19. Michelena HI, Desjardins VA, Avierinos JF, Russo A, Nkomo VT, Sundt TM et al. Natural history of asymptomatic patients with normally functioning or minimally dysfunctional bicuspid aortic valve in the community. Circulation. 2008; 117:2776-84.

20. Sabet HY, Edwards WD, Tazelaar HD, Daly RC. Congenitally bicuspid aortic valves: a surgical pathology study of 542 cases (1991 through 1996) and a literature review of 2,715 additional cases. Mayo Clin Proc. 1999;74:14-26.

21. Fernández B, Durán AC, Fernández-Gallego T, Fernández MC, Such M, Arqué JM, et al. Bicuspid aortic valves with different spatial orientations of the leaflets are distinct etiological entities. J Am Coll Cardiol. 2009;54:2312-8.

22. Robeldo-Carmona J, Rodriguez-Bailòn I, Carrasco-Chinchilla F, Fernàndez B Jimènez-Navarro M, Porras-Marin C, et al. Hereditary patterns of bicuspid aortic valve in a hundred families. Int J Cardiol. 2013;168:3443-9.

23. Mangini A, Lemma M, Contino M, Pettinari M, Gelpi G, Antona C. Bicuspic aortic valve: differences in the phenotypic continuum affect the repair technique. Eur J Cardiothorac Surg. 2010;37:1015-20.

24. Jermihov PN, Jia L, Sacks MS, Gorman RC, Gorman JH III, Chandran KB. Effect of geometry on the leaflet stresses in simulated models of congenital bicuspid aortic valves. Cardiovasc Eng Technol. 2011;2:48-56.

25. Sun L, Chandra S, Sucosky P. Ex vivo evidence for the contribution of hemodynamic shear stress abnormalities to the early pathogenesis of calcific bicuspid aortic valve disease. PLoS One. 2012; 7:e48843.

26. Hayashida K, Bouvier E, Lefèvre T, Chevalier B, Hovasse T, Romano M, et al Transcatheter aortic valve implantation for patients with severe bicuspid aortic valve stenosis. Circ Cardiovasc Interv. 2013;6:284-91.

27. Leon MB, Smith CR, Mack M, Miller DC, Moses JW, Svensson LG, et al; PARTNER Trial Investigators. Transcatheter aortic-valve implantation for 
aortic stenosis in patients who cannot undergo surgery. N Engl J Med. 2010; 363:1597-607.

28. Wijesinghe N, Ye J, Rodés-Cabau J, Cheung A, Velianou JL, Natarajan MK, et al. Transcatheter aortic valve implantation in patients with bicuspid aortic valve stenosis. JACC Cardiovasc Interv. 2010;3:1122-5.

29. Nash PJ, Vitvitsky E, Li J, Cosgrove DM III, Pettersson G, Grimm RA. Feasibility of valve repair for regurgitant bicuspid aortic valves-an echocardiographic study. Ann Thorac Surg. 2005;79:1473-9.

30. Aicher D, Kunihara T, Abou Issa O, Brittner B, Gräber S, Schäfers HJ. Valve configuration determines long-term results after repair of the bicuspid aortic valve. Circulation. 2011;123:178-85.

31. Kunihara T, Aicher D, Rodionycheva S, Groesdonk HV, Langer F, Sata F, et al. Preoperative aortic root geometry and postoperative cusp configuration primarily determine long-term outcome after valve-preserving aortic root repair. J Thorac Cardiovasc Surg. 2012;143:1389-95.

32. Navarra E, El Khoury G, Glineur D, Boodhwani M, Van Dyck M, Vanoverschelde JL, et al. Effect of annulus dimension and annuloplasty on bicuspid aortic valve repair. Eur J Cardiothorac Surg. 2013;44:316-22.

33. Badiu CC, Bleiziffer S, Eichinger WB, Zaimova I, Hutter A, Mazzitelli D, et al. Are bicuspid aortic valves a limitation for aortic valve repair? Eur J Cardiothorac Surg. 2011;40:1097-104.

34. Aicher D, Schneider U, Schmied W, Kunihara T, Tochii M, Schäfers HJ. Early results with annular support in reconstruction of the bicuspid aortic valve. $J$ Thorac Cardiovasc Surg. 2013;145:S30-4.

35. de Kerchove L, Boodhwani M, Glineur D, Vandyck M, Vanoverschelde JL, Noirhomme P, et al. Valve sparing-root replacement with the reimplantation technique to increase the durability of bicuspid aortic valve repair. J Thorac Cardiovasc Surg. 2011;142:1430-8.

36. Etz CD, Misfeld M, Borger MA, Luehr M, Strotdrees E, Mohr FW. Current indications for surgical repair in patients with bicuspid aortic valve and ascending aortic ectasia. Cardiol Res Pract. 2012;2012:313879.

37. Coady MA, Stockwell PH, Robich MP, Poppas A, Sellke FW. Should aortas in patients with bicuspid aortic valve really be resected at an earlier stage than tricuspid? CON. Cardiol Clin. 2010;28:299-314.

38. Wald O, Korach A, Shapira OM. Should aortas in patients with bicuspid aortic valve really be resected at an earlier stage than tricuspid? PRO. Cardiol Clin. 2010;28:289-98.

39. Hiratzka LF, Bakris GL, Beckman JA, Bersin RM, Carr VF, Casey DE Jr, et al. 2010 ACCF/AHA/AATS/ACR/ASA/SCA/ SCAI/SIR/STS/SVM Guidelines for the diagnosis and management of patients with thoracic aortic disease. Task Force on Practice Guidelines, American Association for Thoracic Surgery, American College of Radiology, American Stroke Association, Society of Cardiovascular Anesthesiologists, Society for Cardiovascular Angiography and Interventions, Society of Interventional Radiology, Society of Thoracic Surgeons, and Society for Vascular Medicine. Circulation. 2010;121:e266-369.

40. Guntheroth WG. A critical review of the American College of Cardiology/American Heart Association practice guidelines on bicuspid aortic valve with dilated ascending aorta. Am J Cardiol. 2008;102:107-10.

41. Roberts WC. Prophylactic replacement of a dilated ascending aorta at the time of aortic valve replacement of a dysfunctioning congenitally unicuspid or bicuspid aortic valve. Am J Cardiol. 2011;108:1371-2.

42. Prapa M, Ho SY. Risk stratification in bicuspid aortic valve disease: still more work to do. Eur J Cardiothorac Surg. 2012;41:327-8.

43. Etz CD, Homann TM, Silovitz D, Spielvogel D, Bodian CA, Luehr M, et al. Long-term survival after the Bentall procedure in 206 patients with bicuspid aortic valve. Ann Thorac Surg. 2007;84:1186-93.

44. Nazer RI, Elhenawy AM, Fazel SS, Garrido-Olivares LE, Armstrong S, David TE. The influence of operative techniques on the outcomes of bicuspid aortic valve disease and aortic dilatation. Ann Thorac Surg. 2010;89:1918-24.

45. Svensson LG, Kim KH, Blackstone EH, Rajeswaran J, Gillinov AM, Mihaljevic T, et al. Bicuspid aortic valve surgery with proactive ascending aorta repair. J Thorac Cardiovasc Surg. 2011;142:622-9.

46. Alegret JM, Ligero C, Vernis JM, Beltrán-Debón R, Aragonés G, Duran I, et al. Factors related to the need for surgery after the diagnosis of bicuspid aortic valve: one center's experience under a conservative approach. Int J Med Sci. 2013;10:176-82.

47. Della Corte A, Bancone C, Quarto C, Dialetto G, Covino FE, Scardone M, et al. Predictors of ascending aortic dilatation with bicuspid aortic valve: a wide spectrum of disease expression. Eur J Cardiothorac Surg. 2007;31:397-404.

48. Park CB, Greason KL, Suri RM, Michelena HI, Schaff HV, Sundt TM III. Fate of nonreplaced sinuses of Valsalva in bicuspid aortic valve disease. J Thorac Cardiovasc Surg. 2011;142:278-84.
49. Schaefer BM, Lewin MB, Stout KK, Gill E, Prueitt A, Byers PH, et al. The bicuspid aortic valve: an integrated phenotypic classification of leaflet morphology and aortic root shape. Heart. 2008;94:1634-8.

50. Fazel SS, Mallidi HR, Lee RS, Sheehan MP, Liang D, Fleischman D, et al. The aortopathy of bicuspid aortic valve disease has distinctive patterns and usually involves the transverse aortic arch. J Thorac Cardiovasc Surg. 2008;135:901-7.

51. Della Corte A, Bancone C, Buonocore M, Dialetto G, Covino FE, Manduca S, et al. Pattern of ascending aortic dimensions predicts the growth rate of the aorta in patients with bicuspid aortic valve. JACC Cardiovasc Imaging. 2013;6: 1301-10.

52. Detaint D, Michelena HI, Nkomo VT, Vahanian A, Jondeau G, Sarano ME. Aortic dilatation patterns and rates in adults with bicuspid aortic valves: a comparative study with Marfan syndrome and degenerative aortopathy. Heart. 2014;100:126-34.

53. Girdauskas E, Disha K, Raisin HH, Secknus MA, Borger MA, Kuntze T. Risk of late aortic events after an isolated aortic valve replacement for bicuspid aortic valve stenosis with concomitant ascending aortic dilation. Eur J Cardiothorac Surg. 2012;42:832-8.

54. Della Corte A, Bancone C. Multiple aortopathy phenotypes with bicuspid aortic valve: the importance of terminology and definition criteria. Eur J Cardiothorac Surg. 2012;41:1404.

55. Davies RR, Kaple RK, Mandapati D, Gallo A, Botta DM Jr, Elefteriades JA, et al. Natural history of ascending aortic aneurysms in the setting of an unreplaced bicuspid aortic valve. Ann Thorac Surg. 2007;83:1338-44.

56. Ergin MA, Spielvogel D, Apaydin A, Lansman SL, McCullough JN, Galla JD, et al. Surgical treatment of the dilated ascending aorta: when and how? Ann Thorac Surg. 1999;67:1834-9.

57. Roman MJ, Devereux RB, Kramer-Fox R, O’Loughlin J. Two-dimensional echocardiographic aortic root dimensions in normal children and adults. Am J Cardiol. 1989;64:507-12.

58. Svensson LG, Kim KH, Lytle BW, Cosgrove DM. Relationship of aortic crosssectional area to height ratio and the risk of aortic dissection in patients with bicuspid aortic valves. J Thorac Cardiovasc Surg. 2003;126:892-3.

59. Pape LA, Tsai TT, Isselbacher EM, Oh JK, O'gara PT, Evangelista A, et al; International Registry of Acute Aortic Dissection (IRAD) Investigators. Aortic diameter $>$ or $=5.5 \mathrm{~cm}$ is not a good predictor of type A aortic dissection: observations from the International Registry of Acute Aortic Dissection (IRAD). Circulation. 2007;116:1120-7.

60. Eleid MF, Forde I, Edwards WD, Maleszewski JJ, Suri RM, Schaff HV, et al. Type A aortic dissection in patients with bicuspid aortic valves: clinical and pathological comparison with tricuspid aortic valves. Heart. 2013;99:1668-74.

61. Michelena HI, Khanna AD, Mahoney D, Margaryan E, Topilsky Y, Suri RM, et al. Incidence of aortic complications in patients with bicuspid aortic valves. JAMA. 2011;306:1104-12.

62. Leone O, Biagini E, Pacini D, Zagnoni S, Ferlito M, Graziosi M, et al. The elusive link between aortic wall histology and echocardiographic anatomy in bicuspid aortic valve: implications for prophylactic surgery. Eur J Cardiothorac Surg. 2012;41:322-7.

63. Roberts WC, Vowels TJ, Kitchens BL, Ko JM, Filardo G, Henry AC, et al. Aortic medial elastic fiber loss in acute ascending aortic dissection. Am J Cardiol. 2011; 108:1639-44.

64. Coady MA, Rizzo JA, Hammond GL, Mandapati D, Darr U, Kopf GS, et al. What is the appropriate size criterion for resection of thoracic aortic aneurysm? J Thorac Cardiovasc Surg. 1997; 113:476-91.

65. Ikonomidis JS, Ivey CR, Wheeler JB, Akerman AW, Rice A, Patel RK, et al. Plasma biomarkers for distinguishing etiologic subtypes of thoracic aortic aneurysm disease. J Thorac Cardiovasc Surg. 2013;145:1326-33.

66. Nistri S, Grande-Allen J, Noale M, Basso C, Siviero P, Maggi S, et al. Aortic elasticity and size in bicuspid aortic valve syndrome. Eur Heart J. 2008;29: 472-9.

67. Nathan DP, Xu C, Plappert T, Desjardins B, Gorman JH 3rd, Bavaria JE, et al. Increased ascending aortic wall stress in patients with bicuspid aortic valves. Ann Thorac Surg. 2011;92:1384-9.

68. Gill M, Dunning J. Is reduction aortoplasty (with or without external wrap) an acceptable alternative to replacement of the dilated ascending aorta? Interact Cardiovasc Thorac Surg. 2009;9:693-7.

69. Della Corte A, De Feo M, Bancone C, Provenzano R, Giordano S, Buonocore M, et al. Long-term follow-up of reduction ascending aortoplasty with autologous partial wrapping: for which patient is waistcoat aortoplasty best suited? Interact Cardiovasc Thorac Surg. 2012;14:56-63. 
70. Opotowsky AR, Perlstein T, Landzberg MJ, Colan SD, O'Gara PT, Body SC, et al. A shifting approach to management of the thoracic aorta in bicuspid aortic valve. J Thorac Cardiovasc Surg. 2013;146:339-46.

71. Itoh A, Fischbein M, Arata K, Miller DC. "Peninsula-style" transverse aortic arch replacement in patients with bicuspid aortic valve. Ann Thorac Surg. 2010;90:1369-71.

72. Etz CD, Plestis KA, Homann TM, Bodian CA, Di Luozzo G, Spielvogel D, et al. Reoperative aortic root and transverse arch procedures: a comparison with contemporaneous primary operations. J Thorac Cardiovasc Surg. 2008;136: $860-7$
73. Park CB, Greason KL, Suri RM, Michelena HI, Schaff HV, Sundt TM III. Should the proximal arch be routinely replaced in patients with bicuspid aortic valve disease and ascending aortic aneurysm? J Thorac Cardiovasc Surg. 2011;142: 602-7.

74. Charitos EI, Hanke T, Karluss A, Hilker L, Stierle U, Sievers HH. New insights into bicuspid aortic valve disease: the elongated anterior mitral leaflet. Eur J Cardiothorac Surg. 2013;43:367-70.

75. Pham T, Martin C, Elefteriades J, Sun W. Biomechanical characterization of ascending aortic aneurysm with concomitant bicuspid aortic valve and bovine aortic arch. Acta Biomater. 2013;9:7927-36. 


\section{APPENDIX E1. BAVCon SITES AND INVESTIGATORS}

Harvard Medical School, Department of Anesthesiology, Perioperative and Pain Medicine, Brigham and Women's Hospital, Harvard Medical School, 75 Francis St., Boston, MA 02115. Co-Principal Investigators: Simon C. Body, MBCHB, MPH, FAHA and Eric M. Isselbacher, MD; J Daniel Muehlschlegel, MD; Frederick J. Schoen, MD, $\mathrm{PhD}$; Robert A. Levine, MD; Christine Seidman, MD; Jonathan Seidman, PhD; Thoralf M. Sundt, MD; Calum A. MacRae, MD, PhD; Prem Shekar, MD; Sary F. Aranki, MD.

GenTAC, University of Michigan, Department of Medicine, University of Michigan Medical Center, 1500 East Medical Center Drive, Suite 2131, Ann Arbor, MI 48109-5852. Kim A. Eagle, MD; Barbara L. Kroner, PhD, MPH; Federico Asch, MD.

Mayo Clinic, Department of Medicine, 200 First Street SW, Rochester, MN 55905. Hector I. Michelena, MD; Maurice Enriquez-Sarano, MD, FACC, FAHA; Nandan Anavekar, MD.

Monaldi Hospital - AO Colli, Department of Cardiothoracic Sciences, Division of Cardiology SUN, via L Bianchi, Napoli, Campania, 80,131, Italy. Limongelli Giuseppe, $\mathrm{MD}, \mathrm{PhD}$; Maria Giovanna Russo, MD, PhD; Fiorella Fratta, MD, PhD; Berardo Sarubbi, MD, PhD; Antonello D'Andrea, MD, PhD; Giuseppe Pacileo, MD; Giovanni Di Salvo, MD, PhD; Giancarlo Scognamiglio, MD; Raffaella Esposito, MD; Marianna Carrozza, MD, PhD; Melina Morelli, MD; Alessandra Rea, MD; Concetta Ricci, MD.

University of Ottawa, 550 Cumberland, Ottawa, Ontario, K1N 6N5, Canada. Mona Nemer, PhD.

University of Oxford, Division of Cardiovascular Medicine, John Radcliffe Hospital, Headley Way, Oxford, OX3 9DU, United Kingdom. Malenka M. Bissell, MD, BM, MRCPCh.

Heart Department, University Hospital of Salerno, Salerno, Italy. Eduardo Bossone, MD, PhD; Rodolfo Citro, MD, $\mathrm{PhD}$; Giuseppe Di Benedetto, MD, PhD; Francesco Ferrara, $\mathrm{MD}, \mathrm{PhD}$.

San Donato, Istituto Policlinico San Donato, Division of Cardiac Surgery, San Donato Hospital, Piazza Edmondo Malan 1, Milan, 20097, Italy. Alessandro Frigiola, MD;
Andrea Ballotta, MD; Francesca Pluchinotta, MD; Alessandro Varrica, MD.

Second University of Naples, Dipartimento di Scienze Cardiotoraciche e Respiratorie, Division of Cardiac Surgery, via L Bianchi, Napoli, 80,131, Italy. Alessandro Della Corte, MD, PhD; Marisa De Feo, MD, PhD; Ciro Bancone, MD, PhD; Giovanni Dialetto, MD; Franco E. Covino, MD; Sabrina Manduca, MD; Marianna Buonocore, MD; Gianantonio Nappi, MD.

Tufts University School of Medicine, Tufts Medical Center, 800 Washington Street, Boston, MA 02111. Gordon Huggins, MD.

University of Liège, GIGA Cardiovascular Sciences, University Hospital of Liège, CHU Sart Tilman, Liège, Belgium. Patrizio Lancelotti, MD, PhD, Natzi Sakalihasan, $\mathrm{MD}, \mathrm{PhD}$.

Université Laval, Department of Molecular Medicine, Centre de recherche Institut Universitaire de Cardiologie et de Pneumologie de Québec, 2725 chemin Ste-Foy, Québec, G1V-4G5, Canada. Yohan Bossé, PhD; Patrick Mathieu, MD, FRCSC; Philippe Pibarot, DVM, PhD; Marie-Chloé Boulanger, $\mathrm{PhD}$.

University of Michigan, University of Michigan Medical Center, 2344 Cardiovascular Center, 1500 E. Medical Center Drive, Ann Arbor, MI 48109-5853. Anna M. Booher, MD.

University of Pennsylvania, Division of Cardiothoracic Surgery, Hospital of the University of Pennsylvania, 3400 Spruce Street, Philadelphia, PA 19104. Rita K. Milewski, $\mathrm{RPh}, \mathrm{MD}, \mathrm{PhD}$; Joseph Bavaria, MD.

University of Texas, Department of Medicine, University of Texas Health Science Center at Houston, 6431 Fannin St., Houston, TX 77030. Dianna M. Milewicz, MD, PhD; Siddharth Prakash, MD, PhD.

Hospital Vall d'Hebron, Department of Cardiology, Hospital Universitari Vall d'Hebron, Paseo Vall d'Hebron 119129, Barcelona, 08,035, Spain. Arturo Evangelista, MD; Jose Rodriguez-Palomares, MD; Gisela Teixido Tura, MD.

Vanderbilt University, Department of Medicine, Vanderbilt University Medical Center, 2209 Garland Avenue, Nashville, TN 37232. Joshua C Denny, MD, MS; Peter Weeke, MD. 